Article

\title{
Effect of Nutrient Solution Concentration on the Growth of Hydroponic Sweetpotato
}

\author{
Masaru Sakamoto *(D) and Takahiro Suzuki \\ Faculty of Biology-Oriented Science and Technology, Kindai University, Wakayama 649-6493, Japan; \\ tksuzuki@waka.kindai.ac.jp \\ * Correspondence: sakamoto@waka.kindai.ac.jp; Tel.: +81-0736773888
}

Received: 24 September 2020; Accepted: 3 November 2020; Published: 4 November 2020

check for updates

\begin{abstract}
Nutrient solution concentration (NSC) is a critical factor affecting plant growth in hydroponics. Here, we investigated the effects of hydroponic NSC on the growth and yield of sweetpotato (Ipomoea batatas (L.) Lam.) plants. First, sweetpotato cuttings were cultivated hydroponically in three different NSCs with low, medium, or high electrical conductivity (EC; $0.8,1.4$, and $2.6 \mathrm{dS} \mathrm{m}^{-1}$, respectively). Shoot growth and storage root yield increased at 143 days after plantation (DAP), depending on the NSC. Next, we examined the effect of NSC changes at half of the cultivation period on the growth and yield, using high and low NSC conditions. In plants transferred from high to low EC (HL plants), the number of attached leaves increased toward the end of the first half of the cultivation period (73 DAP), compared with plants transferred from low to high EC (LH plants). Additionally, the number of attached leaves decreased in HL plants from 73 DAP to the end of the cultivation period (155 DAP), whereas this value increased in LH plants. These changes occurred due to a high leaf abscission ratio in HL plants. The storage root yield showed no significant difference between HL and LH plants. Our results suggest that the regulation of hydroponic NSC during the cultivation period affects the growth characteristics of sweetpotato.
\end{abstract}

Keywords: nutrient solution concentration; hydroponics; sweetpotato; storage root; leaf abscission

\section{Introduction}

Sweetpotato (Ipomoea batatas) is an important root vegetable cultivated in temperate and tropical zones, especially in Asia and Africa [1]. Storage roots of sweetpotato contain relatively high amounts of carbohydrates that support the demand for food in developing countries [2,3]. In recent years, sweetpotato has been also evaluated as a candidate for biofuel production [4,5]. Sweetpotato could potentially be used as an alternative to corn-based ethanol production to reduce fertilizer, water, and pesticide inputs and to utilize its ability to fix relatively large amounts of solar energy into starch in storage roots [6,7]. Several efficient methods of extracting biofuels and their residues (hydrogen, ethanol, and methane) from sweetpotato have been reported to date [5,8-11]. Because the demand for sweetpotato is gradually increasing worldwide [12], it is necessary to establish an efficient and cheap cultivation method with low fertilizer requirement.

Fertilizers are widely used in agriculture to increase crop production. In sweetpotato, soil amendment using manure and inorganic fertilizers has a significant impact on plant growth and storage root development [13]. Among chemical fertilizers, nitrogen $(\mathrm{N})$, phosphorus (P), and potassium (K) are the major elements required for supporting shoot and root growth in sweetpotato [14,15]. Under $\mathrm{N}$ 
deficient conditions, the application of $\mathrm{N}$ fertilizers significantly increases the storage root weight [16-18]. The relative proportion of $\mathrm{N}$ and $\mathrm{K}$ fertilizers applied also affects the storage root yield, photosynthesis product distribution, and leaf enzyme activities in field-grown sweetpotato [19-21]. Administration of an adequate quantity of $\mathrm{K}$ fertilizer $\left(\mathrm{K}_{2}\right.$ was supplied to $\left.300 \mathrm{~kg} \mathrm{ha}^{-1}\right)$ has shown to increase the ratio of storage root yield relative to the total yield [22]. Furthermore, $\mathrm{N}$ application rate influences the lateral root development at the early growth stage, with $50 \mathrm{~kg} \mathrm{ha}^{-1}$ application being the most developed [23]. These early root developments are thought to the initiation of storage root formation [24].

In hydroponics, fertilizers are supplied as ions in the nutrient solution [25]. Several formulations of essential macro- and micronutrients have been developed to enhance nutrient uptake and plant growth [26]. Because the nutrient solution is the only source of mineral nutrients in hydroponically-grown plants, extremely low concentrations of nutrients generally leads to growth inhibition [27]. On the other hand, extremely high nutrient solution concentration (NSC) causes osmotic stress, ionic toxicity, and growth restriction [27]. Several studies have demonstrated that NSC influences the growth and components of spinach, tomato, cucumber, salvia, bean, artichoke, wasabi, and lettuce plants [28-37]. In a hydroponic NSC with high electrical conductivity (EC), the growth of tomato plants was restricted, whereas the level of sugars and lycopene in tomato fruits, and consequently fruit quality, were enhanced [30]. In strawberry, flower bud initiation was promoted by treatment with low NSC [38-40].

Sweetpotato plants fail to develop storage roots under continuous waterlogging conditions [41-43]. Therefore, several studies have established hydroponic methods of sweetpotato cultivation to avoid soaking the hypertrophic sites of roots in water [41-49]. Substrates that ensure proper root aeration, such as rockwool, vermiculite, and sand, have been used for the hydroponic cultivation of sweetpotato [43-45]. Additionally, rockwool slab-based hydroponic systems have been demonstrated to produce thickened sweetpotato storage roots between the hydroponic solution surface and rockwool slabs [46]. Similarly, the nutrient film technique and modified deep flow technique have been shown to induce storage root formation at an area where roots are not continuously immersed in the hydroponic solution [41,47-49]. Although some hydroponic methods for sweetpotato have been developed to date, studies on sweetpotato hydroponic NSC are limited. Here, using previously developed vermiculite-based hydroponic methods [43], we investigated the effect of NSC on the growth and yield of sweetpotato.

\section{Materials and Methods}

\subsection{Experimental Conditions}

Sweetpotato (Ipomoea batatas) cultivar "Narutokintoki" was used in this study. The hydroponics system for sweetpotato was prepared as described previously [43]. Briefly, this system consisted of vermiculite-filled vinyl pots $(4.5 \mathrm{~L})$ placed in nutrient solution-filled containers $(59 \mathrm{~cm} \times 39 \mathrm{~cm} \times 18 \mathrm{~cm})$. Storage roots developed in vinyl pots, and fibrous roots of sweetpotato plants extended from the upper vinyl pots into the containers placed below. Plants could absorb the nutrient solution from the vermiculite, as the bottom of each pot was in direct contact with the water absorption sheet that extended into the nutrient solution below. Therefore, vermiculite in vinyl pots remained saturated with the nutrient solution throughout the cultivation period. The surface of pots and bottom containers was covered with insulation sheets to maximize the utilization of sunlight by reflection for photosynthesis. The nutrient solution was prepared by mixing OAT house 1: OAT house 2 (OAT Agrio Co., Ltd., Tokyo, Japan) at a ratio of 3:2, and the NSC was adjusted to obtain the target EC (described below). The mixed nutrient solution contains $\mathrm{N}, 260 \mathrm{mg} \mathrm{L}^{-1}, \mathrm{P}_{2} \mathrm{O}_{5}, 120 \mathrm{mg} \mathrm{L}^{-1} ; \mathrm{K}_{2} \mathrm{O}, 405 \mathrm{mg} \mathrm{L}^{-1} ; \mathrm{CaO}, 230 \mathrm{mg} \mathrm{L}^{-1} ; \mathrm{MgO}, 60 \mathrm{mg} \mathrm{L}^{-1} ; \mathrm{MnO}_{1} 1.5 \mathrm{mg} \mathrm{L}^{-1}$; $\mathrm{B}_{2} \mathrm{O}_{3}, 1.5 \mathrm{mg} \mathrm{L}^{-1} ; \mathrm{Fe}, 2.7 \mathrm{mg} \mathrm{L}^{-1} ; \mathrm{Cu}, 0.03 \mathrm{mg} \mathrm{L}^{-1}$; $\mathrm{Zn}, 0.09 \mathrm{mg} \mathrm{L}^{-1}$ and $\mathrm{Mo}, 0.03 \mathrm{mg} \mathrm{L}^{-1}$. Reduction in the water level in the tank due to evaporation was compensated by adding more water to the maximum 
level. Therefore, the EC of the NSC in each tank gradually decreased over time (Supplementary Figure S1). The nutrient solution was renewed approximately once every 30 days.

Two separate experiments were conducted (experiment 1 in 2018, and experiment 2 in 2019) to examine the effect of NSC on the growth and yield of sweetpotato (Figure 1). In experiment 1, three NSCs, each with low $\left(0.8 \mathrm{dS} \mathrm{m}^{-1}\right)$, medium $\left(1.4 \mathrm{dS} \mathrm{m}^{-1}\right)$, or high $\left(2.6 \mathrm{dS} \mathrm{m}^{-1}\right) \mathrm{EC}$, were used throughout the cultivation period, and the effect of each NSC on plant growth was observed. The initial pH of high, medium, and low NSCs were 6.14, 6.46, and 6.72, respectively. In experiment 2, effects of changes in NSC on plant growth were examined using nutrient solutions with low EC $\left(0.8 \mathrm{dS} \mathrm{m}^{-1}\right)$ and high EC $\left(2.6 \mathrm{dS} \mathrm{m}^{-1}\right)$. Four treatments were conducted in experiment 2: (1) LL, plants were grown in low EC nutrient solution throughout the cultivation period; (2) LH, plants were grown in low EC nutrient solution until the end of the first half of the cultivation period, and then transferred to high EC nutrient solution and maintained until the end of the cultivation period; (3) HL, plants grown in high EC nutrient solution were transferred to low EC nutrient solution at the end of the first half of the cultivation period and maintained thereafter; (4) $\mathrm{HH}$, plants were grown in high EC nutrient solution throughout the cultivation period.

\section{Experiment 1}

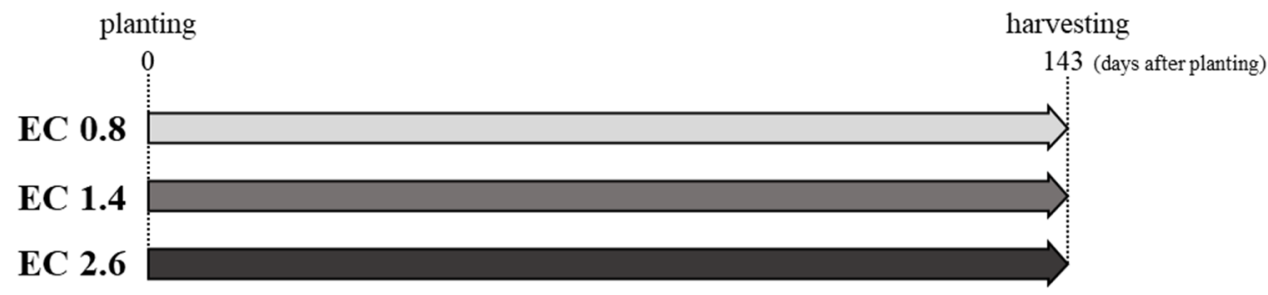

Experiment 2

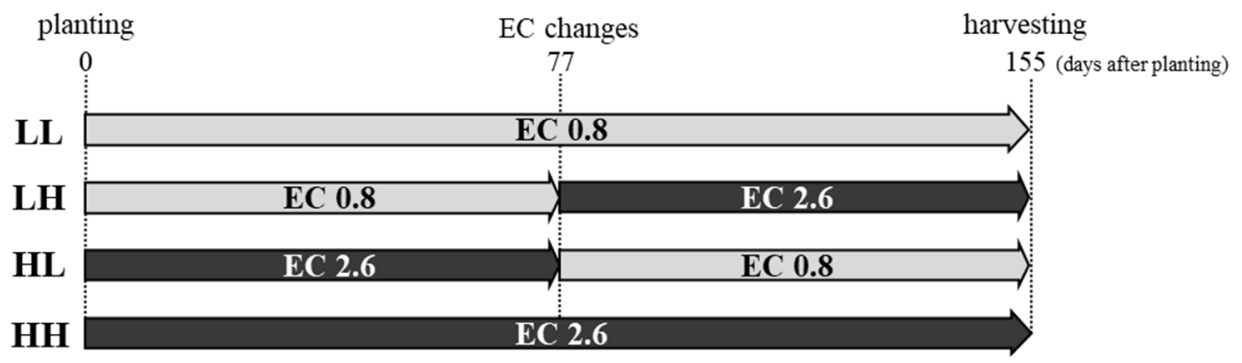

Figure 1. Experimental design. EC: electrical conductivity.

In experiment 1 , sweetpotato stem cuttings were planted in vermiculite-filled vinyl pots and grown for 18 days by drenching in nutrient solution with medium EC $\left(1.4 \mathrm{dS} \mathrm{m}^{-1}\right)$. The experiment was started by transferring the pots to the hydroponic system with different NSCs (four pots per container). Plants were then cultivated for 143 days (from 29 May to 19 October in 2018) at the open experimental field of Kindai University (Faculty of Biology-Oriented Science Technology, Wakayama, Japan). The average temperature of Wakayama city in 2018 were $19.7{ }^{\circ} \mathrm{C}, 23.2{ }^{\circ} \mathrm{C}, 28.8{ }^{\circ} \mathrm{C}, 29.1{ }^{\circ} \mathrm{C}, 24 .{ }^{\circ} \mathrm{C}$, and $19.5^{\circ} \mathrm{C}$ in May, June, July, August, September, and October, respectively, according to the website of Japan Meteorological Agency [50]. The average relative humidity was $69 \%, 77 \%, 74 \%, 69 \%, 78 \%$, and $67 \%$ in May, June, July, August, September, and October, respectively [50]. The experimental field is about $17 \mathrm{~km}$ away from the meteorological station in Wakayama City, and $90 \mathrm{~m}$ higher than the station. The nutrient solution was renewed on 26 June, 31 July, and 30 August. In experiment 2, stem cuttings were planted in pots and 
grown for 25 days under the same growth conditions as those used for experiment 1 . Pots were then transferred to the hydroponic system and cultivated for 155 days (from 18 May to 20 October in 2019) at the open experimental field of Kindai University. The average temperature of Wakayama city in 2019 was $20.1{ }^{\circ} \mathrm{C}, 23.5^{\circ} \mathrm{C}, 26.3^{\circ} \mathrm{C}, 28.5^{\circ} \mathrm{C}, 26.4^{\circ} \mathrm{C}$, and $20.7{ }^{\circ} \mathrm{C}$ in May, June, July, August, September, and October, respectively [51]. The average relative humidity was $60 \%, 72 \%, 79 \%, 76 \%, 71 \%$, and $73 \%$ in May, June, July, August, September, and October, respectively [51]. The nutrient solution was renewed on 22 June, 12 July, 3 August, 31 August, and 28 September. The EC of the nutrient solution was changed for HL and LH plants on 3 August 2019.

\subsection{Measurement of Plant Growth and Yield}

In experiments 1 and 2, shoot and storage root fresh weight (FW) and storage root number were measured at 143 and 155 days after planting (DAP), respectively. Enlarged roots weighing more than $20 \mathrm{~g}$ were included as storage roots. In experiment 2 , the number of attached leaves and the maximum length of the stem were measured at 3, 73, and 155 DAP. Total leaf number, abscised leaf ratio, stem number, and stem diameter were measured at 155 DAP. The number of total leaves was counted by adding the number of attached leaves and leaf petioles (without leaves). The abscised leaf ratio was calculated by dividing the number of total leaves with the number of attached leaves. In experiments 1 and 2, all measurements were recorded as the average of eight plants.

\subsection{Measurement of Chlorophyll Contents}

Relative chlorophyll contents were measured via a nondestructive assay using the Soil and Plant Analyzer Development (SPAD) chlorophyll meter (SPAD-502; Konica Minolta, Tokyo, Japan). Measurements were conducted at 3, 73, and 153 DAP using the second young fully expanded leaf of each plant.

\subsection{Data Analysis}

Data were analyzed using the JMP statistical package (SAS Institute, Cary, NC, USA). Significant differences among treatments were determined by one-way analysis of variance, followed by the Tukey-Kramer honest significant difference test for pairwise comparisons at $p<0.05$.

\section{Results}

\subsection{Effect of NSC on the Growth of Hydroponic Sweetpotato (Experiment One)}

Experiment one was conducted to examine the effect of NSC on the growth of sweetpotato in a hydroponic system. At 143 DAP, the shoot FW was the highest in the nutrient solution with high EC, followed by medium EC, and low EC (Figure 2A). The storage root FW showed the same trend as that described above (Figure 2B). Additionally, the number of storage roots showed no significant difference among the three treatments (Figure 2C). 

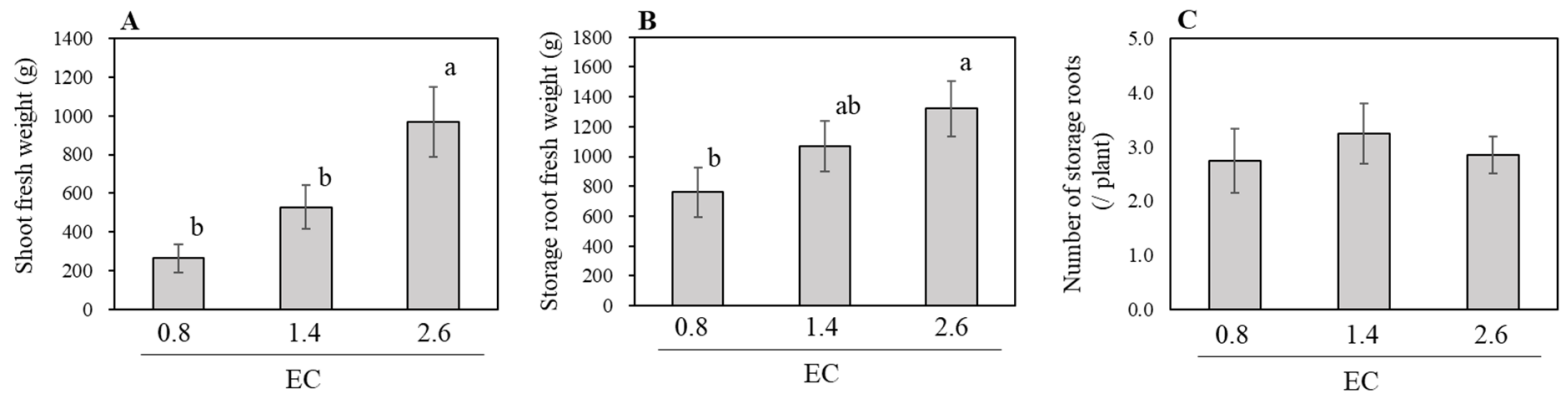

Figure 2. Effects of nutrient solution concentration on shoot fresh weight (A), storage root fresh weight (B), and number of storage roots $(\mathbf{C})$ of sweetpotato at 143 days after plantation in experiment 1 . Vertical bars represent the means $\pm \mathrm{SE}(n=8)$. Different letters indicate significant differences among the treatments at $p<0.05$ by Tukey-Kramer's test.

\subsection{Effect of Variation in NSC on the Growth of Hydroponic Sweetpotato (Experiment Two)}

Next, we examined whether changes in NSC affect the growth of hydroponic sweetpotato. Plant shoot growth was measured at three time points: 3 DAP, 73 DAP (4 days before changing the NSC), and 155 DAP (harvest day). The leaf chlorophyll content increased from 3 to 73 DAP in all plants, reaching similar levels in all treatments (Figure 3A). No significant differences were detected among treatments at each time point, although the leaf chlorophyll contents of $\mathrm{HH}$ and LH plants at $155 \mathrm{DAP}$ tended to be higher than that of HL and LL plants (Figure 3A). The number of attached leaves was higher in HH and HL plants than in LH and LL plants at 73 DAP (Figure 3B). Compared with 73 DAP, the number of attached leaves at 155 DAP was approximately 1.51-fold change in HH plants, 0.58 -fold change in HL plants, 2.84-fold change in LH plants, and 1.09-fold change in LL plants (Figure 3B). Reduction in the number of attached leaves during cultivation suggests the induction of leaf abscission. This coincides with the pictures of shoots of HL plants at 155 DAP showing that leaves were rarely attached to the petiole at the bottom and middle sections of the stem (Figure 4). To examine leaf abscission, we counted the number of total leaves, including previously abscised leaves, at 155 DAP. HH plants showed the highest number of total leaves, followed LH, HL, and LL plants (Table 1). The abscised leaf ratio was the highest in HL plants, followed by LL, HH, and LH plants (Table 1).

Table 1. Effects of nutrient solution concentration on number of total leaves and abscised leaf ratio of sweetpotato at 155 days after plantation in experiment 2. Different letters indicate significant differences among the treatments at $p<0.05$ by Tukey-Kramer's test.

\begin{tabular}{ccc}
\hline Treatment & Number of Total Leaves & Abscised Leaf Ratio (\%) \\
\hline LL & $277 \mathrm{c}$ & $63.6 \mathrm{ab}$ \\
$\mathrm{LH}$ & $545 \mathrm{ab}$ & $58.9 \mathrm{c}$ \\
$\mathrm{HL}$ & $417 \mathrm{bc}$ & $72.9 \mathrm{a}$ \\
$\mathrm{HH}$ & $761 \mathrm{a}$ & $66.9 \mathrm{ab}$
\end{tabular}

LL: plants were grown in low EC nutrient solution throughout the cultivation period; LH: plants were grown in low EC nutrient solution until the end of the first half of the cultivation period, and then transferred to high EC nutrient solution and maintained until the end of the cultivation period; HL: plants grown in high EC nutrient solution were transferred to low EC nutrient solution at the end of the first half of the cultivation period and maintained thereafter; HH: plants were grown in high EC nutrient solution throughout the cultivation period. 
At 73 DAP, the maximum shoot length was higher in HH and HL plants than in LH and LL plants (Figure 3C). At 155 DAP, shoot length was the highest in HH plants and lowest in LL plants, while HL and LH plants showed similar intermediate shoot lengths (Figure 3C). The number of stems was significantly higher in $\mathrm{HH}$ plants compared with plants in the other treatments (Figure 5A). Stem diameter was the highest in HH plants, followed by HL and LH plants, and the lowest in LL plants (Figure 5B).
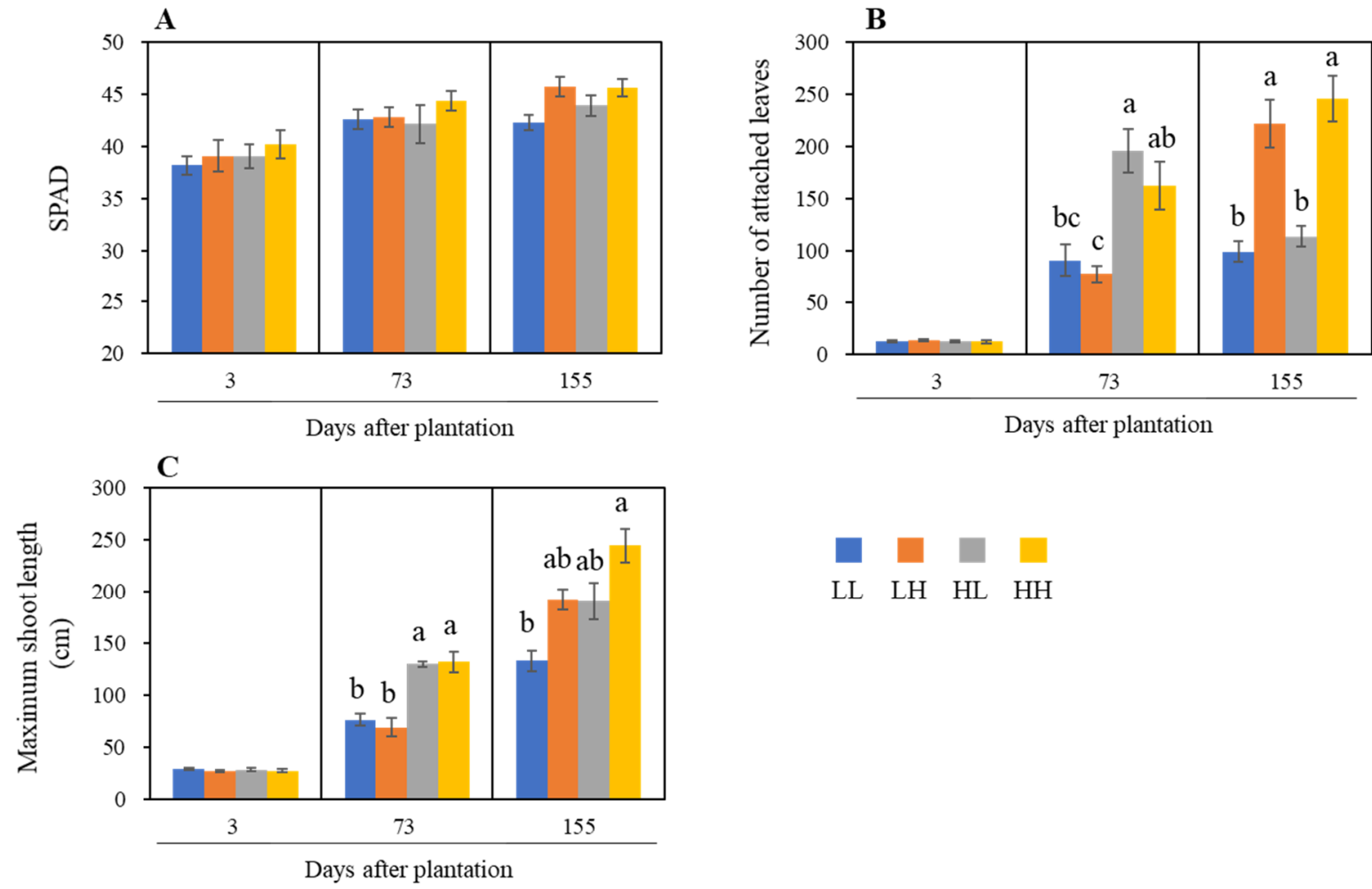

LL $\quad$ LH $\quad$ HL $\quad$ HH

Figure 3. Effects of nutrient solution concentration on number of attached leaves (A), maximum shoot length (B), and the Soil and Plant Analyzer Development (SPAD) (C) of sweetpotato in experiment 2. These parameters were examined after 3, 73, and 155 days after plantation. Vertical bars represent the means \pm SE $(n=8)$. Different letters indicate significant differences among the treatments at $p<0.05$ by Tukey-Kramer's test. 

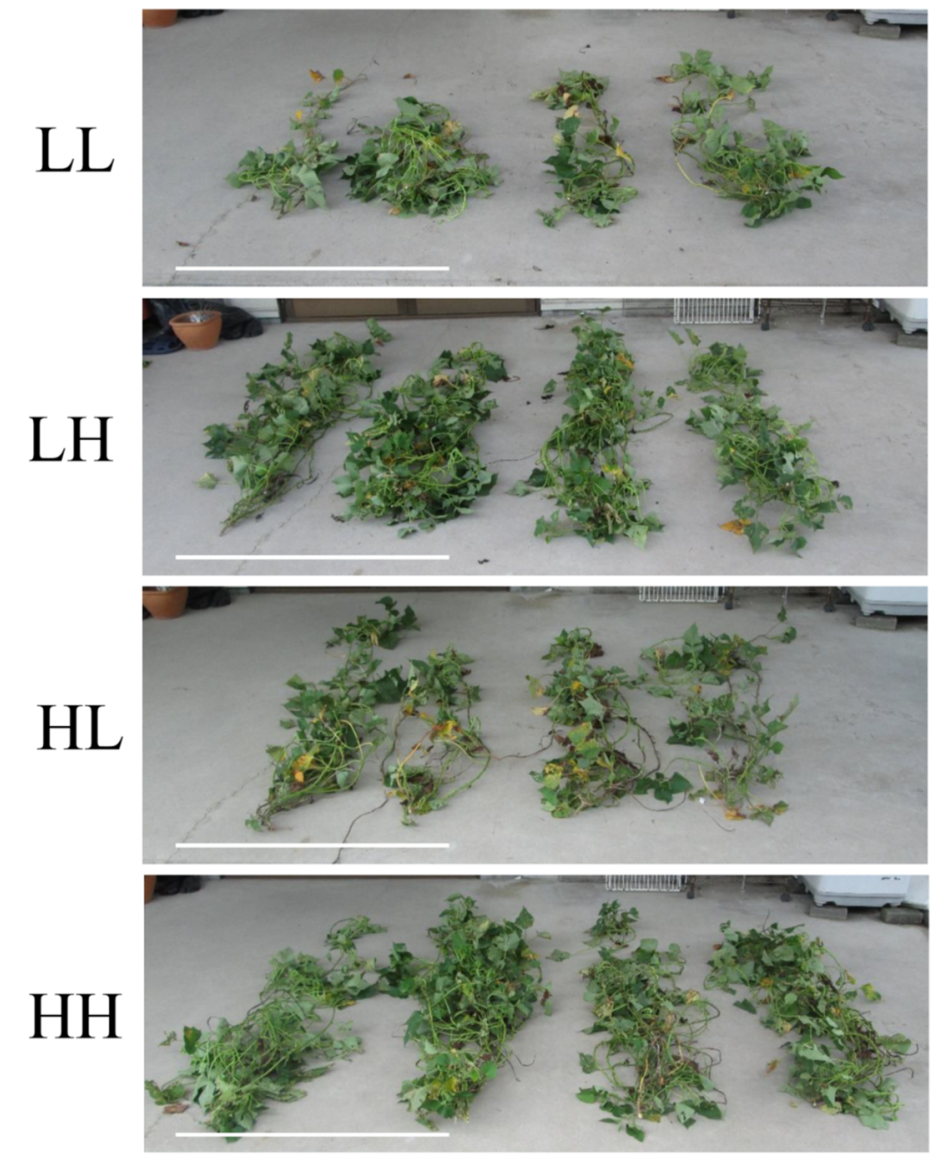

Figure 4. Effects of nutrient solution concentration on the shoot morphology of sweetpotato at 155 days after plantation in experiment 2 . Scale bars $=47 \mathrm{~cm}$.
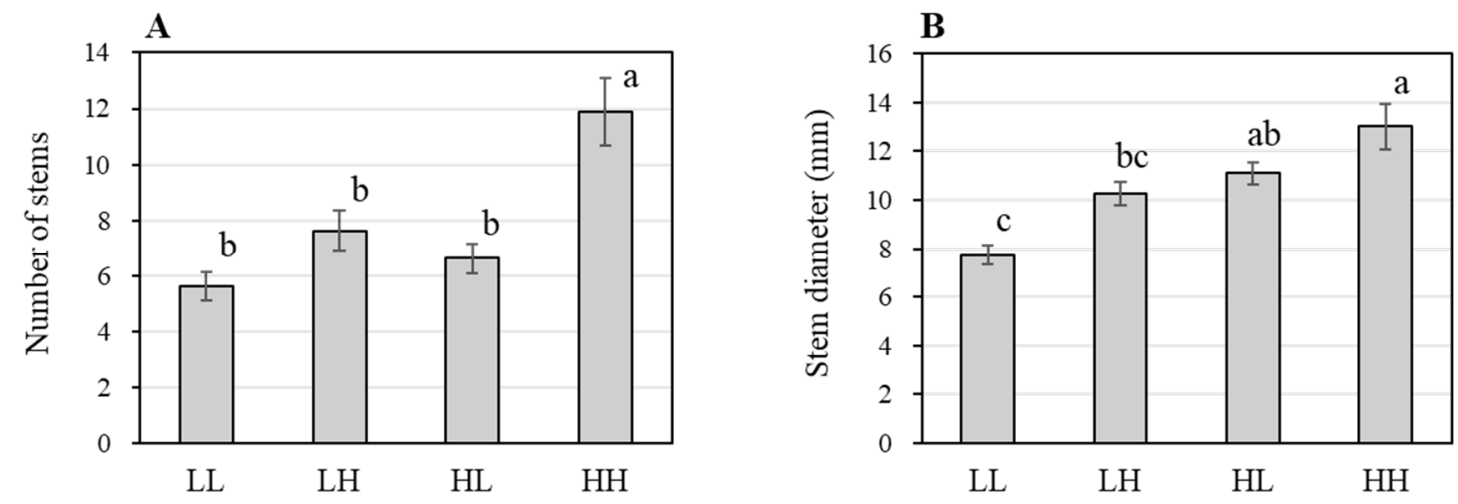

Figure 5. Effects of nutrient solution concentration on number of stems (A) and stem diameter (B) of sweetpotato at 155 days after plantation in experiment 2 . Vertical bars represent the means $\pm \operatorname{SE}(n=8)$. Different letters indicate significant differences among the treatments at $p<0.05$ by Tukey-Kramer's test.

The biomass of shoots and storage roots was measured at 155 DAP. Shoot FW was the highest in HH plants, followed by LH, HL, and LL plants (Figure 6A). Storage root FW was the highest in HH plants, followed by HL and LH plants, and the lowest in LL plants (Figure 6B). The number of storage roots showed no significant difference among treatments (Figure 6C). Storage roots developed within vinyl pots 
in all treatments. Storage roots were round in shape, with a short length and partially undeveloped parts (Figure 7), consistent with previous observations [43]. These morphological characteristics of storage roots exhibited no variation among the different treatments (Figure 7).
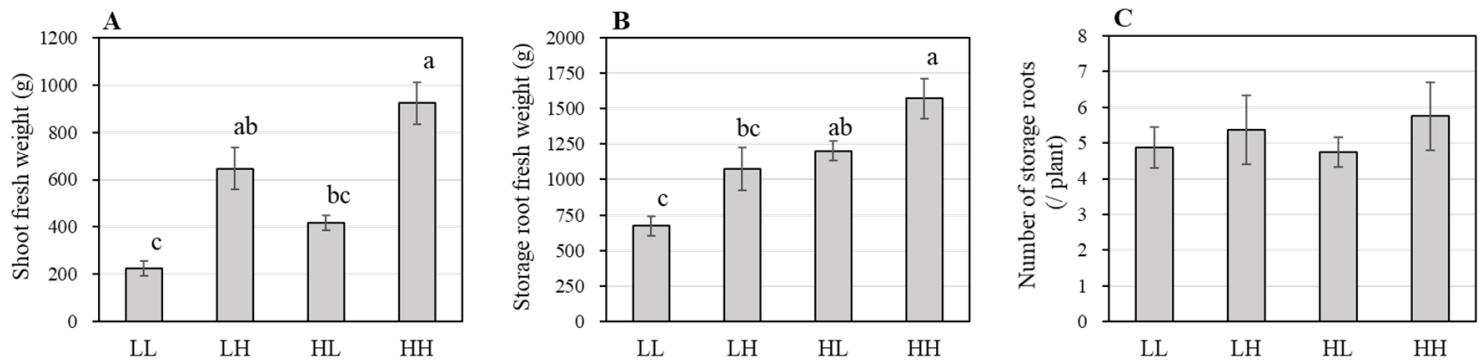

Figure 6. Effect of nutrient solution concentration on shoot fresh weight (A), storage root fresh weight (B), and number of storage roots $(\mathrm{C})$ of sweetpotato at 155 days after plantation in experiment 2 . Vertical bars represent the means $\pm \mathrm{SE}(n=8)$. Different letters indicate significant differences among the treatments at $p<0.05$ by Tukey-Kramer's test.

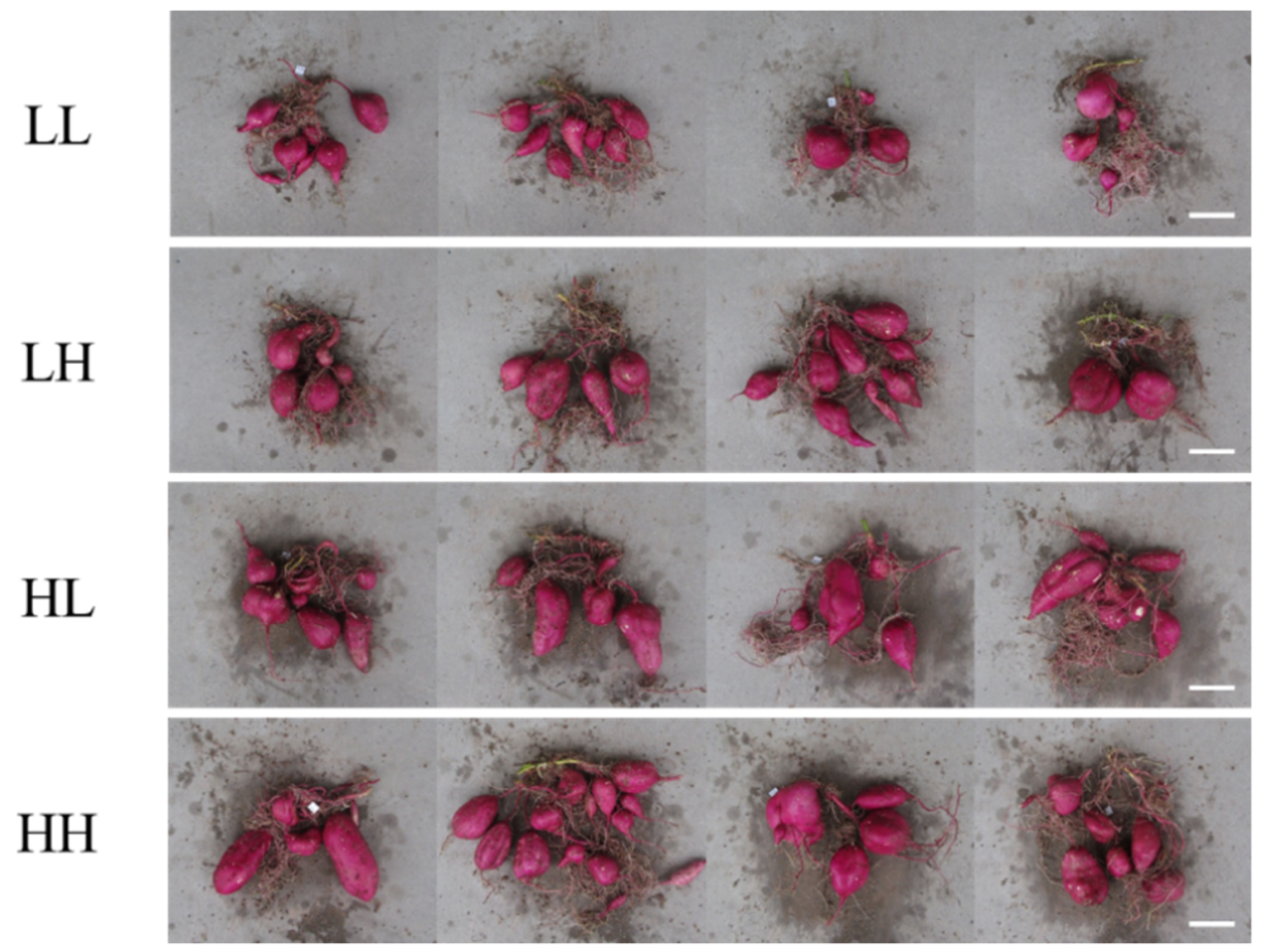

Figure 7. Effect of nutrient solution concentration on the storage root morphology of sweetpotato at 155 days after plantation in experiment 2 . Scale bars $=10 \mathrm{~cm}$.

\section{Discussion}

In hydroponics, the optimal NSC varies among plant species, with EC ranging from 1.5 to $2.5 \mathrm{dS} \mathrm{m}^{-1}$ [52,53]. Several studies have shown that high NSCs reduce the growth and photosynthetic parameters of hydroponically-grown plants [30,32,35,54-56]. High NSC-dependent growth restrictions are observed at EC $>1.8 \mathrm{dS} \mathrm{m}^{-1}$ in peace lily and at EC $>2.8 \mathrm{dS} \mathrm{m}^{-1}$ in peppermint and lettuce [37,54,55]. By contrast, hydroponically-grown bush snap beans can tolerate EC up to $3.6 \mathrm{dS} \mathrm{m}^{-1}$ [33]. In the current 
study, the growth of shoots and storage roots of hydroponic sweetpotatoes increased in an NSC-dependent manner up to an EC of $2.6 \mathrm{dS} \mathrm{m}^{-1}$ (Figure 2). Given that continuous growth of sweetpotato plants in a nutrient solution with an EC of $2.6 \mathrm{dS} \mathrm{m}^{-1}$ did not influence the leaf chlorophyll content (Figure 3A), this NSC appears to be more favorable for plant growth and storage root development rather than an osmotic stress condition that would deter growth and photosynthetic activity.

Plants sense the nutrient dose and alter the biomass partitioning accordingly [57]. In sweetpotato, the dose of $\mathrm{N}$ fertilizer alters the biomass partitioning of storage roots and shoots $[58,59]$. Increasing the $\mathrm{N}$ fertilizer dose from 0 to $1.2 \mathrm{~g} \mathrm{~N}$ per plant increases the biomass partitioning to storage roots [58]. However, at a higher $\mathrm{N}$ dose, the storage root biomass decreases, whereas the shoot biomass increases [58]. In experiment one, the growth of shoots and storage roots were enhanced as the NSC increased to an EC of $2.6 \mathrm{dS} \mathrm{m}^{-1}$ (Figure 2A,B). Considering the reports that hydroponic plants have different growth characteristics compared with soil grown plants $[60,61]$, the responsiveness of hydroponically-grown sweetpotato to the nutrient dose might be different from that of soil grown sweetpotato plants. In hydroponic potatoes, shoot growth was enhanced when NSC was increased up to EC $2.4 \mathrm{dS} \mathrm{m}^{-1}$, whereas tuber biomass was not affected by the EC of the nutrient solution [56]. Therefore, NSC-dependent partitioning of biomass may differ among plant species in hydroponics. The number of storage roots tend to be higher in experiment two (Figure 6C) compared to experiment one (Figure 2C). This may be caused by the different cultivation periods between experiments. Because two experiments were conducted only one time, the data may be influenced by the environmental condition.

The nutritional requirements of plants vary with the developmental stage [62]. Several studies have shown that changes in NSC influence plant growth characteristics [29,63-66]. In strawberry, restriction of $\mathrm{N}$ application at an early developmental stage increased the fruit biomass by enhancing reproductive growth [63]. In hydroponic tomato, increasing the NSC during fruit development reduces the fruit size and increases the sugar content [66]. Nutrient solution formulations have been developed for various growth stages in hydroponic tomato [67]. In sweetpotato, the timing of $\mathrm{N}$ fertilizer application influences plant growth and storage root yield [68-71]. Split application of $\mathrm{N}$ fertilizer could increase the storage root yield of sweetpotato by improving the efficiency of $\mathrm{N}$ uptake $[69,70]$. The timing of $\mathrm{N}$ fertilizer application is also important for increasing the marketable sweetpotato yield [71]. In experiment two, the storage root FW showed no significant difference between HL and LH plants (Figure 6B). This suggests that the timing of high-dose $\mathrm{N}$ application is not important for storage root development in hydroponically-grown sweetpotato. On the other hand, the shoot biomass and total leaf number were higher in LH plants compared with HL plants (Figure 6A, Table 1). These results implicate that higher dose of nutrient application at the storage root hypertrophic stage (the second half of growth stage) may enhance the development of shoots as well as storage roots. It should also take into account for the high abscised leaf ratio in HL plants (Table 1) because the abscised leaves, which did not contribute to shoot biomass, were partly responsible for the low shoot FW of HL plants. In general, at the late stage of sweetpotato cultivation, the storage root growth is enhanced, whereas shoot growth is retarded [59]. Thus, nutrient limiting condition at the hypertrophic stage of storage roots in HL plants may represent the field-grown sweetpotato characteristics in the shoot and root development. Because the amount of photosynthetic products translocated to storage roots partly depends on the shoot biomass, modifying the timing of NSC changes might improve the storage root yield.

Leaf abscission occurs during the senescence process and is induced by various stress responses [72]. Before the onset of leaf cell separation, the abscission zone encounters the repression of auxin biosynthesis and enhancement of ethylene production and sensitivity, resulting in the activation of cell wall degradation enzymes [73-75]. In experiment two, leaf abscission was induced at the late stage of cultivation in all NSC treatments (Table 1). This growth stage-dependent leaf abscission in sweetpotato has also been observed in open field conditions [76-78], suggesting a consistent senescence related phenomenon. $\mathrm{N}$ or $\mathrm{P}$ limitation is 
known to induce leaf abscission by enhancing ethylene production and sensitivity [79]. Sweetpotato leaves also abscise at the late growth stage under low $\mathrm{N}$ or P condition [80]. In HL plants, plant shoot biomass (the number of attached leaves and maximum shoot length) increased during the first half of the cultivation period in the nutrient solution with high EC (Figure 3B,C); however, these shoots grew in relatively poor nutrient conditions during the second half of the cultivation period. These nutrient poor conditions might trigger the high ratio of leaf abscission associated with $\mathrm{N}$ or $\mathrm{P}$ deficiency. Leaf senescence is accompanied by the breakdown of chlorophyll [81]. HL and LL plants showed a higher abscised leaf ratio and lower relative chlorophyll content (Figure 3A, Table 1), suggesting accelerated leaf abscissions by the progression of senescence. $\mathrm{N}$ deficiency also causes oxidative stress to the leaf [82]. Given that oxidative stress could trigger leaf abscission [83-86], it is possible that HL plants exhibit leaf abscission during the second half of the cultivation period due to oxidative stress triggered by $\mathrm{N}$ deficiency. On the other hand, LH plants were relatively nutrient-rich condition at the late cultivation period. Therefore, leaf senescence and abscission were thought to be suppressed by relatively rich-N supplement.

\section{Conclusions}

Compared to traditional soil culture systems, sweetpotato hydroponics saves absorbent material (soil) and can be used anywhere exposed to sunlight. In addition, hydroponics can efficiently utilize nutrient components as supplied components are not dispersed to the soil. In fact, almost all nutrients were absorbed in plants grown on EC 0.8 and 1.4 in this study (Supplementary Figure S1). Here, we presented NSC-dependent storage root yield in hydroponic sweetpotato (experiment one). Although the timing of high and low NSC did not have a significant impact on the storage root yield, shoot growth was apparently increased by high NSC (experiment two). A more precise adjustment of the NSC may increase the yield of storage roots relative to the fertilizer input. Thus, given its flexibility in manipulating the nutrient status, hydroponics could be used as an efficient tool for sweetpotato production.

Supplementary Materials: The following are available online at http://www.mdpi.com/2073-4395/10/11/1708/s1, Figure S1: Time-course changes of nutrient solution EC in experiment 1 . The nutrient solution was renewed on June 26.EC was measured two containers of each experimental plot.

Author Contributions: Conceptualization, M.S. and T.S.; formal analysis, M.S.; investigation, M.S.; writing-original draft preparation, M.S.; writing—review and editing, M.S. and T.S. All authors have read and agreed to the published version of the manuscript.

Funding: This research was partly funded by the Japan Society for the Promotion of Science (JSPS), KAKENHI Grant Number 20K12247 to T.S. and 20K06329 to M.S.

Acknowledgments: The authors thank Kokoro Kubota, Takashi Tobe, Kaito Nakano, Daisuke Fukada, Hyuki Kishida, and Rihito Yamabe for supporting the field experiments.

Conflicts of Interest: The authors declare no conflict of interest.

\section{References}

1. Petsakos, A.; Prager, S.D.; Gonzalez, C.E.; Gama, A.C.; Sulser, T.B.; Gbegbelegbe, S.; Kikulwe, E.M.; Hareau, G. Understanding the consequences of changes in the production frontiers for roots, tubers and bananas. Glob. Food Secur. 2019, 20, 180-188. [CrossRef]

2. Woolfe, J. Sweet Potato: An Untapped Food Resource, 1st ed.; Cambridge University Press: New York, NY, USA, 1992; p. 643.

3. Pimentel, D.; Doughty, R.; Carothers, C.; Lamberson, S.; Bora, N.; Lee, K. Energy inputs in crop production in developing and developed countries. In Food Security and Environmental Quality in the Developing World; CRC Press: Boca Raton, FL, USA, 2002; pp. 129-151.

4. Koçar, G.; Civaş, N. An overview of biofuels from energy crops: Current status and future prospects. Renew. Sustain. Energy Rev. 2013, 28, 900-916. [CrossRef] 
5. Lareo, C.; Ferrari, M.D. Sweet Potato as a Bioenergy Crop for Fuel Ethanol Production: Perspectives and Challenges. In Bioethanol Production from Food Crops; Academic Press: New York, NY, USA, 2019; pp. $115-147$.

6. Ziska, L.H.; Runion, G.B.; Tomecek, M.; Prior, S.A.; Torbet, H.A.; Sicher, R. An evaluation of cassava, sweet potato and field corn as potential carbohydrate sources for bioethanol production in Alabama and Maryland. Biomass Bioenergy 2009, 33, 1503-1508. [CrossRef]

7. e Silva, J.O.V.; Almeida, M.F.; da Conceição Alvim-Ferraz, M.; Dias, J.M. Integrated production of biodiesel and bioethanol from sweet potato. Renew. Energy 2018, 124, 114-120. [CrossRef]

8. Chu, C.Y.; Sen, B.; Lay, C.H.; Lin, Y.C.; Lin, C.Y. Direct fermentation of sweet potato to produce maximal hydrogen and ethanol. Appl. Energy 2012, 100, 10-18. [CrossRef]

9. Lay, C.H.; Lin, H.C.; Sen, B.; Chu, C.Y.; Lin, C.Y. Simultaneous hydrogen and ethanol production from sweet potato via dark fermentation. J. Clean. Prod. 2012, 27, 155-164. [CrossRef]

10. Kobayashi, T.; Tang, Y.; Urakami, T.; Morimura, S.; Kida, K. Digestion performance and microbial community in full-scale methane fermentation of stillage from sweet potato-shochu production. J. Environ. Sci. 2014, 26, 423-431. [CrossRef]

11. Wang, F.; Jiang, Y.; Guo, W.; Niu, K.; Zhang, R.; Hou, S.; Wang, M.; Yi, Y.; Zhu, C.; Jia, C.; et al. An environmentally friendly and productive process for bioethanol production from potato waste. Biotechnol. Biofuels $2016,9,50$. [CrossRef]

12. Monteiro, R.L.; de Moraes, J.O.; Domingos, J.D.; Carciofi, B.A.M.; Laurindo, J.B. Evolution of the physicochemical properties of oil-free sweet potato chips during microwave vacuum drying. Innov. Food Sci. Emerg. Technol. 2020, 63, 102317. [CrossRef]

13. Nedunchezhiyan, M.; Byju, G.; Jata, S.K. Sweet potato agronomy. Fruit Veg. Cereal Sci. Biotechnol. 2012, 6, 1-10.

14. Halavatau, S.; O'Sullivan, J.N.; Asher, C.J.; Blamey, F.P.C. Better nutrition improves sweet potato and taro yields in the South Pacific. Trop. Agric. 1998, 75, 6-12.

15. Laxminarayana, K.; John, K.S.; Ravindran, C.S.; Naskar, S.K. Effect of lime, inorganic, and organic sources on soil fertility, yield, quality, and nutrient uptake of sweet potato in Alfisols. Commun. Soil Sci. Plant Anal. 2011, 42, 2515-2525. [CrossRef]

16. Sawahata, H. Studies on the Characteristics of the Thickening of Storage Root of Sweet Potato: II. Influence of the supply of mineral nutrients on the thickening of storage root. Jpn. J. Crop Sci. 1989, 58, 290-296. [CrossRef]

17. Osaki, M.; Ueda, H.; Shinano, T.; Matsui, H.; Tadano, T. Accumulation of carbon and nitrogen compounds in sweet potato plants grown under deficiency of N, P, or K nutrients. Soil Sci. Plant Nutr. 1995, 41, 557-566. [CrossRef]

18. Taranet, P.; Harper, S.; Kirchhof, G.; Fujinuma, R.; Menzies, N. Growth and yield response of glasshouse-and field-grown sweetpotato to nitrogen supply. Nutr. Cycl. Agroecosyst. 2017, 108, 309-321. [CrossRef]

19. Jia, Z.D.; Ma, P.Y.; Bian, X.F.; Guo, X.D.; Xie, Y.Z. The effects of different $\mathrm{N}$ and $\mathrm{K}$ fertilizer ratio and planting density on yield and dry matter accumulation of sweetpotato. Acta Agric. Boreali-Sin. 2012, 27, 321-327.

20. Wang, S.Y.; Li, H.; Liu, Q.; Shi, Y.X. Interactive effects of nitrogen and potassium on root growth and leaf enzyme activities of sweet potato. Acta Agric. Boreali-Sin. 2015, 30, 167-173.

21. Wang, S.; Liu, Q.; Shi, Y.; Li, H.; Wang, S.; Liu, Q.; Shi, Y.; Li, H. Interactive effects of nitrogen and potassium on photosynthesis product distribution and accumulation of sweetpotato. Sci. Agric. Sin. 2017, 50, $2706-2716$.

22. George, M.S.; Lu, G.; Zhou, W. Genotypic variation for potassium uptake and utilization efficiency in sweet potato (Ipomoea batatas L.). Field Crop. Res. 2002, 77, 7-15. [CrossRef]

23. Villordon, A.; LaBonte, D.; Firon, N.; Carey, E. Variation in nitrogen rate and local availability alter root architecture attributes at the onset of storage root initiation in 'Beauregard' sweetpotato. HortScience 2013, 48, 808-815. [CrossRef]

24. Villordon, A.Q.; Ginzberg, I.; Firon, N. Root architecture and root and tuber crop productivity. Trends Plant Sci. 2014, 19, 419-425. [CrossRef] [PubMed]

25. Savvas, D. Hydroponics: A modern technology supporting the application of integrated crop management in greenhouse. J. Food Agric. Environ. 2003, 1, 80-86. 
26. Jones, J.B., Jr. Hydroponics: Its history and use in plant nutrition studies. J. Plant Nutr. 1982, 5, 1003-1030. [CrossRef]

27. Savvas, D.; Adamidis, K. Automated management of nutrient solutions based on target electrical conductivity, $\mathrm{pH}$, and nutrient concentration ratios. J. Plant Nutr. 1999, 22, 1415-1432. [CrossRef]

28. Öztekin, G.B.; Uludağ, T.; Tüzel, Y. Growing spinach (Spinacia oleracea L.) in a floating system with different concentrations of nutrient solution. Appl. Ecol. Environ. Res. 2018, 16, 3333-3350. [CrossRef]

29. Sakamoto, Y.; Watanabe, S.; Nakashima, T.; Okano, K. Effects of salinity at two ripening stages on the fruit quality of single-truss tomato grown in hydroponics. J. Hortic. Sci. Biotechnol. 1999, 74, 690-693. [CrossRef]

30. Wu, M.; Kubota, C. Effects of electrical conductivity of hydroponic nutrient solution on leaf gas exchange of five greenhouse tomato cultivars. HortTechnology 2008, 18, 271-277. [CrossRef]

31. Wanzheng, M.; Hanping, M.; Jing, H.; Jiheng, N.; Zhongfang, L. Effects of different nutrient solution concentration on the growth and development of cucumber in greenhouse. In Proceedings of the 2011 International Conference on New Technology of Agricultural, Zibo, China, 27-29 May 2011; IEEE: New York, NY, USA, 2011; pp. $277-281$.

32. Kang, J.G.; van Iersel, M.W. Nutrient solution concentration affects shoot: Root ratio, leaf area ratio, and growth of subirrigated salvia (Salvia splendens). HortScience 2004, 39, 49-54. [CrossRef]

33. Valdez, M.T.; Ito, T.; Shinohara, Y.; Maruo, T. Effects of nutrient solution levels on the growth, yield and mineral contents in hydroponically-grown bush snap bean. Environ. Control Biol. 2002, 40, 167-175. [CrossRef]

34. Rouphael, Y.; Cardarelli, M.; Lucini, L.; Rea, E.; Colla, G. Nutrient solution concentration affects growth, mineral composition, phenolic acids, and flavonoids in leaves of artichoke and cardoon. HortScience 2012, 47, 1424-1429. [CrossRef]

35. Hoang, N.N.; Kitaya, Y.; Shibuya, T.; Endo, R. Development of an in vitro hydroponic culture system for wasabi nursery plant production-Effects of nutrient concentration and supporting material on plantlet growth. Sci. Hortic. 2019, 245, 237-243. [CrossRef]

36. Shinohara, Y.; Suzuki, Y. Effects of light and nutritional conditions on the ascorbic acid content of lettuce. J. Jpn. Soc. Hortic. Sci. 1981, 50, 239-246. [CrossRef]

37. Fallovo, C.; Rouphael, Y.; Rea, E.; Battistelli, A.; Colla, G. Nutrient solution concentration and growing season affect yield and quality of Lactuca sativa L. var. acephala in floating raft culture. J. Sci. Food Agric. 2009, 89, 1682-1689. [CrossRef]

38. Sarooshi, R.A.; Cresswell, G.C. Effects of hydroponic solution composition, electrical conductivity and plant spacing on yield and quality of strawberries. Aust. J. Exp. Agric. 1994, 34, 529-535. [CrossRef]

39. Lieten, P. The effect of nutrition prior to and during flower differentiation on phyllody and plant performance of short day strawberry Elsanta. Acta Hortic. 2002, 567, 345-348. [CrossRef]

40. Gallace, N.; Boonen, M.; Lieten, P.; Bylemans, D. Electrical conductivity of the nutrient solution: Implications for flowering and yield in day-neutral cultivars. Acta Hortic. 2017, 1156, 223-228. [CrossRef]

41. Eguchi, T.; Yoshida, S. A cultivation method to ensure tuberous root formation in sweetpotatoes (Ipomoea batatas (L.) Lam.). Environ. Control Biol. 2004, 42, 259-266. [CrossRef]

42. Eguchi, T.; Moriyama, S.; Miyajima, I.; Yoshida, S.; Chikushi, J. A hydroponic method suitable for tops production of a sweetpotato [Ipomoea batatas] cultivar 'Suioh'. J. Sci. High Technol. Agric. 2007, 19, 167-174. [CrossRef]

43. Sakamoto, M.; Suzuki, T. Effect of pot volume on the growth of sweetpotato cultivated in the new hydroponic system. Sustain. Agric. Res. 2018, 7, 137-145. [CrossRef]

44. Kitaya, Y.; Hirai, H.; Endo, R.; Shibuya, T. Effects of water contents and $\mathrm{CO}_{2}$ concentrations in soil on growth of sweet potato. Field Crops Res. 2013, 152, 36-43.

45. Eguchi, T.; Ito, Y.; Yoshida, S. Periodical wetting increases $\alpha$-tocopherol content in the tuberous roots of sweetpotato (Ipomoea batatas (L.) Lam.). Environ. Control Biol. 2012, 50, 297-303. [CrossRef]

46. Kitaya, Y.; Hirai, H.; Wei, X.; Islam, A.F.M.S.; Yamamoto, M. Growth of sweetpotato cultured in the newly designed hydroponic system for space farming. Adv. Space Res. 2008, 41, 730-735. [CrossRef]

47. Mortley, D.G.; Loretan, P.A.; Bonsi, C.K.; Hill, W.A.; Morris, C.E. Plant spacing influences yield and linear growth rate of sweetpotatoes grown hydroponically. HortScience 1991, 26, 1274-1275. [CrossRef] 
48. Almazan, A.M.; Zhou, X. Biomass yield and composition of sweetpotato grown in a nutrient film technique system. Plant Foods Hum. Nutr. 1997, 50, 259-268. [CrossRef]

49. Uewada, T. The solution culture of sweet potatoes. Environ. Control Biol. 1990, 28, 135-140. [CrossRef]

50. Japan Meteorological Agency Official Website. Past Weather Data of Wakayama City in 2018. Available online: http://www.data.jma.go.jp/obd/stats/etrn/view/monthly_s1.php?prec_no=65\&block_no=47777\&year=2018\& month $=\&$ day $=\& v i e w=p 1$ (accessed on 23 September 2020).

51. Japan Meteorological Agency Official Website. Past Weather Data of Wakayama City in 2019. Available online: http://www.data.jma.go.jp/obd/stats/etrn/view/monthly_s1.php?prec_no=65\&block_no=47777\&year=2019\& month=\&day=\&view=p1 (accessed on 23 September 2020).

52. Sonneveld, C.; Voogt, W. Plant Nutrition of Greenhouse Crops; Springer: Dordrecht, The Netherlands, 2009; pp. 393-403.

53. Trejo-Téllez, L.I.; Gómez-Merino, F.C. Nutrient solutions for hydroponic systems. In Hydroponics: A Standard Methodology for Plant Biological Researches; Asao, T., Ed.; InTechOpen: Rjeka, Croatia, 2012; pp. 1-22.

54. Dewir, Y.H.; Chakrabarty, D.; Ali, M.B.; Hahn, E.J.; Paek, K.Y. Effects of hydroponic solution EC, substrates, PPF and nutrient scheduling on growth and photosynthetic competence during acclimatization of micropropagated Spathiphyllum plantlets. Plant Growth Regul. 2005, 46, 241-251. [CrossRef]

55. Tabatabaie, S.J.; Nazari, J. Influence of nutrient concentrations and $\mathrm{NaCl}$ salinity on the growth, photosynthesis, and essential oil content of peppermint and lemon verbena. Turk. J. Agric. For. 2007, 31, 245-253.

56. Chang, D.C.; Cho, I.C.; Suh, J.T.; Kim, S.J.; Lee, Y.B. Growth and yield response of three aeroponically grown potato cultivars (Solanum tuberosum L.) to different electrical conductivities of nutrient solution. Am. J. Potato Res. 2011, 88, 450-458. [CrossRef]

57. Hermans, C.; Hammond, J.P.; White, P.J.; Verbruggen, N. How do plants respond to nutrient shortage by biomass allocation? Trends Plant Sci. 2006, 11, 610-617. [CrossRef] [PubMed]

58. Kelm, M.; Brück, H.; Hermann, M.; Sattelmacher, B. Plant Productivity and Water Use Efficiency of Sweetpotato (Ipomoea batatas) as Affected by Nitrogen Supply; CIP Program Report 1999-2000; International Potato Center: Lima, Peru, 2000; pp. 273-279.

59. Osaki, M.; Ueda, H.; Shinano, T.; Matsui, H.; Tadano, T. Accumulation of carbon and nitrogen compounds in sweet potato plants grown under different nitrogen application rates. Soil Sci. Plant Nutr. 1995, 41, 547-555. [CrossRef]

60. Manzocco, L.; Foschia, M.; Tomasi, N.; Maifreni, M.; Dalla Costa, L.; Marino, M.; Cortella, G.; Cesco, S. Influence of hydroponic and soil cultivation on quality and shelf life of ready-to-eat lamb's lettuce (Valerianella locusta L. Laterr). J. Sci. Food Agric. 2011, 91, 1373-1380. [CrossRef]

61. Miller, M.H.; Walker, G.K.; Tollenaar, M.; Alexander, K.G. Growth and yield of maize (Zea mays L.) grown outdoors hydroponically and in soil. Can. J. Soil Sci. 1989, 69, 295-302. [CrossRef]

62. Fageria, N.K.; Baligar, V.C. Enhancing nitrogen use efficiency in crop plants. Adv. Agron. 2005, 88, 97-185.

63. Yoshida, Y.; Fujime, Y.; Chujo, T. Effects of nitrogen nutrition on flower bud development and fruit malformation in 'Ai-Berry' strawberry. J. Jpn. Soc. Hortic. Sci. 1992, 60, 869-879. [CrossRef]

64. Dittakit, P.; Thongket, T. Increased nutrient solution concentration during early fruit development stages enhances pungency and phenylalanine ammonia-lyase activity in hot chili (Capsicum annuum L.). Am. J. Agric. Biol. Sci. 2014, 9, 72. [CrossRef]

65. Maruyama, S.; Ishigami, Y.; Goto, E. Effect of nutrient solution concentration at the heading time on the growth, development, and seed storage protein content of rice plants in a controlled environment. Environ. Control Biol. 2010, 48, 17-24. [CrossRef]

66. Wu, M.; Kubota, C. Effects of high electrical conductivity of nutrient solution and its application timing on lycopene, chlorophyll and sugar concentrations of hydroponic tomatoes during ripening. Sci. Hortic. 2008, 116, 122-129. [CrossRef]

67. Hochmuth, G.J.; Hochmuth, R.C. Nutrient Solution Formulation for Hydroponic (Perlite, Rockwool, NFT) Tomatoes in Florida; HS796; University of Florida Cooperative Extension Service: Gainesville, FL, USA, 2001. 
68. Ankumah, R.O.; Khan, V.; Mwamba, K.; Kpomblekou-A, K. The influence of source and timing of nitrogen fertilizers on yield and nitrogen use efficiency of four sweet potato cultivars. Agric. Ecosyst. Environ. 2003, 100, 201-207. [CrossRef]

69. Du, X.; Xi, M.; Kong, L. Split application of reduced nitrogen rate improves nitrogen uptake and use efficiency in sweetpotato. Sci. Rep. 2019, 9, 1-11. [CrossRef]

70. Du, X.; Zhang, X.; Xi, M.; Kong, L. Split application enhances sweetpotato starch production by regulating the conversion of sucrose to starch under reduced nitrogen supply. Plant Physiol. Biochem. 2020, 151, 743-750. [CrossRef] [PubMed]

71. Phillips, S.B.; Warren, J.G.; Mullins, G.L. Nitrogen rate and application timing affect 'Beauregard' sweetpotato yield and quality. HortScience 2005, 40, 214-217. [CrossRef]

72. Patharkar, O.R.; Walker, J.C. Connections between abscission, dehiscence, pathogen defense, drought tolerance, and senescence. Plant Sci. 2019, 284, 25-29. [CrossRef]

73. Liljegren, S.J. Organ abscission: Exit strategies require signals and moving traffic. Curr. Opin. Plant Biol. 2012, 15, 670-676. [CrossRef] [PubMed]

74. Patterson, S.E.; Bolivar-Medina, J.L.; Falbel, T.G.; Hedtcke, J.L.; Nevarez-McBride, D.; Maule, A.F.; Zalapa, J.E. Are we on the right track: Can our understanding of abscission in model systems promote or derail making improvements in less studied crops? Front. Plant Sci. 2016, 6, 1268. [CrossRef]

75. Patharkar, O.R.; Walker, J.C. Advances in abscission signaling. J. Exp. Bot. 2018, 69, 733-740. [CrossRef]

76. Somda, Z.C.; Kays, S.J. Sweet potato canopy morphology: Leaf distribution. J. Am. Soc. Hortic. Sci. 1990, 115, 39-45. [CrossRef]

77. Somda, Z.C.; Mahomed, M.T.M.; Kays, S.J. Analysis of leaf shedding and dry matter recycling in sweetpotato. J. Plant Nutr. 1991, 14, 1201-1212. [CrossRef]

78. McLaurin, W.J.; Kays, S.J. Substantial leaf shedding-A consistent phenomenon among high-yielding sweetpotato cultivars. HortScience 1993, 28, 826-827. [CrossRef]

79. Lynch, J.; Brown, K.M. Ethylene and plant responses to nutritional stress. Physiol. Plant. 1997, 100, 613-619. [CrossRef]

80. Bouwkamp, J.C. Sweet potato products: A Natural Resource for the Tropics; CRC Press: Boca Taton, FL, USA, 1985.

81. Matile, P.; Hortensteiner, S.; Thomas, H.; Krautler, B. Chlorophyll breakdown in senescent leaves. Plant Physiol. 1996, 112, 1403-1409. [CrossRef]

82. Huang, Z.A.; Jiang, D.A.; Yang, Y.; Sun, J.W.; Jin, S.H. Effects of nitrogen deficiency on gas exchange, chlorophyll fluorescence, and antioxidant enzymes in leaves of rice plants. Photosynthetica 2004, 42, 357-364. [CrossRef]

83. Sakamoto, M.; Munemura, I.; Tomita, R.; Kobayashi, K. Involvement of hydrogen peroxide in leaf abscission signaling, revealed by analysis with an in vitro abscission system in Capsicum plants. Plant J. 2008, 56, 13-27. [CrossRef]

84. Sakamoto, M.; Munemura, I.; Tomita, R.; Kobayashi, K. Reactive oxygen species in leaf abscission signaling. Plant Signal. Behav. 2008, 3, 1014-1015. [CrossRef] [PubMed]

85. Bar-Dror, T.; Dermastia, M.; Kladnik, A.; Žnidarič, M.T.; Novak, M.P.; Meir, S.; Burd, S.; Philosoph-Hadas, S.; Ori, N.; Sonego, L.; et al. Programmed cell death occurs asymmetrically during abscission in tomato. Plant Cell 2011, 23, 4146-4163. [CrossRef]

86. Liao, W.; Wang, G.; Li, Y.; Wang, B.; Zhang, P.; Peng, M. Reactive oxygen species regulate leaf pulvinus abscission zone cell separation in response to water-deficit stress in cassava. Sci. Rep. 2016, 6, 1-17. [CrossRef] [PubMed]

Publisher's Note: MDPI stays neutral with regard to jurisdictional claims in published maps and institutional affiliations.

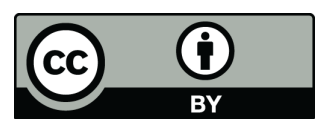

(C) 2020 by the authors. Licensee MDPI, Basel, Switzerland. This article is an open access article distributed under the terms and conditions of the Creative Commons Attribution (CC BY) license (http://creativecommons.org/licenses/by/4.0/). 